\title{
Seasonal variation of locomotion and energy expenditure in goats under range grazing conditions
}

\author{
M. LACHICA, F.G. BARROSO, AND C. PRIETO
}

Authors are researcher, Dept. Animal Nutrition Estación Experimental del Zaidin (CS/C), Professor Albareda, 1.18008 Granada; professor Dept. Applied Biology, University of Alueria, La Canada de San Urbano, 04120 Aluerio; researcher Dept. Animal Nutrition, Estación Experimental del Zaidin (CSIC), Profesor Albareda, 1., 18008 Granada, SPAIN.C. Prieto passed away since the mansucript was accepted.

\begin{abstract}
Energy cost of various activities can be used in conjunction with direct field observations to estimate energy expended in the daily activities of free-ranging animals. The objective of this study was to estimate the energy expenditure due to locomotion of goats on open range. The study was carried out at the 130-ha "Los Pajares" pilot zone, located in the Filabres mountain-range, Almeria. Average elevation is $865 \mathrm{~m}$ above sea level. The area has a Mediterranean climate. The mean annual precipitation is $324 \mathrm{~mm}$. The average daily temperatures range from $8.9^{\circ} \mathrm{C}$ in January to $23.0^{\circ} \mathrm{C}$ in August. The landscape is characterized by woody plants and perennial grasses.

The experimental flock was grazed on its customary routes for 2 days during 4 seasons. The goats were released to graze during the day and then returned to an enclosed shed. Direct observation was used to simulate the total distance walked, the vertical ascent or descent, and to quantify other grazing activities. The energy expenditure of locomotion was calculated from the horizontal and vertical components of travel and the corresponding costs, which had been previously obtained by calorimetry. Daily travel distances by goats on range fluctuated from $5,763 \mathrm{~m}$ in summer to $3,482 \mathrm{~m}$ in autumn, with an annual average of 4,295 $\mathrm{m}$, which represents a mean speed of $10.8 \mathrm{~m} / \mathrm{min}$. The mean annual vertical ascent or descent was $168 \mathrm{~m}$. Estimated heat production due to locomotion ranged from 56.9 to $34.8 \mathrm{~kJ} / \mathrm{kg}^{0.75}$ per day in summer and autumn respectively. These values account for an increased energy requirement at pasture above maintenance of 14.2 and $8.7 \%$, respectively.
\end{abstract}

Key Words: goats, locomotion, grazing, heat production

Goats are well adapted to the hot and dry conditions of the semi-arid areas of southern Spain, being the domestic animal species with the greatest productivity in such climatic conditions. Goats are able to obtain an adequate diet even when forage is scarce and they can feed over rugged and otherwise inaccesible terrain. The distance travelled by the grazing goat has important bearing on its productive performance and may be influenced by

\footnotetext{
This work was supported by LUCDEME Program (CSIC-ICONA).

The authors would like to thank J.D. Luna, professor at the Department of Biostatistics, Faculty of Medicine, University of Granada, for statistical help.

Manuscript received 23 May 1996.
}

seasonal variation in grazing activities.

Ruminants expend much more energy outdoors than indoors. Animals on range spend considerably more time walking, eating, and foraging for food than confined animals which magnify their energy expenditure. The maintenance energy requirements of grazing ruminants has been reported (Table 1) to be from $0>$ $100 \%$ greater than for animals in confinement, with the cost of travel contributing substantially to this increase. In arid lands, goats have to travel long distances for adequate food and water, and thus, their energy expenditure increase severalfold.

There have been several attemps to measure energy expenditure of grazing animals (Osuji 1974, Whitelaw 1974, Brockway 1978 and Prieto et al. 1992). Data on the energy requirements of grazing animals have been derived from estimates of feed intakes for constant liveweight (Wallace 1955, Reid 1958, Corbett et al. 1961, Coop and Hill 1962, Hutton 1962, Lambourne and Reardon

Table 1. The energy requirements for maintenance in ruminants. Comparison between estimates made with animsls housed indoors and those of similar animals at pasture.

\begin{tabular}{|c|c|c|c|}
\hline \multicolumn{2}{|c|}{$\operatorname{MEm}(\mathrm{MJ} / \mathrm{d})$} & \multirow[b]{2}{*}{ Increase } & \multirow[b]{2}{*}{ References } \\
\hline Indoors & At pasture & & \\
\hline
\end{tabular}

Cattle

(\%)

\begin{tabular}{|c|c|c|c|}
\hline- & - & 15.0 & ${ }^{1}$ Blaxter (1967) \\
\hline 50.6 & 50.6 & 0 & ${ }^{1}$ Corbett et al. (1961) \\
\hline 50.6 & 77.8 & 53.8 & 'Reid (1958) \\
\hline 50.6 & 88.3 & 74.4 & ${ }^{1}$ Wallace (1955) \\
\hline 50.6 & $77.0-104.6$ & $52.2-106.7$ & ${ }^{1}$ Hutton (1962) \\
\hline
\end{tabular}

Sheep

$\begin{array}{cccc}- & - & 11.0 & { }^{1} \text { Blaxter(1967) } \\ 6.7 & 8.4 & 25.4 & { }^{1} \text { Langlands et al. (1963) } \\ 5.9 & 9.6-11.3 & 62.7-91.5 & { }^{1} \text { Coop and Hill (1962) } \\ 5.9 & 8.8 & 49.2 & { }^{1} \text { Lambournen and Reardon(1963) } \\ - & - & 60.0-70.0 & { }^{2} \text { Young and Corbett (1972) } \\ 5.3 & 7.0 & 32.1 & { }^{3} \text { Osuji (1974) }\end{array}$

Goat

$\begin{array}{cccc}- & - & 25 / 50 / 75 & { }^{4} \mathrm{NRC}(1981) \\ 6.3 & 7.0 & 11.1 & { }^{5} \text { Present work }\end{array}$

Estimates of feed intake for constant live weight.

${ }_{2}^{2}$ Direct measurements at pasture (CERT and MIC)

${ }^{3}$ By using the energy cost of different activities and their duration at pasture.

${ }^{4}$ Maintenance plus low, medium or high level of activity.

5 Taking into account the extra costs associated to locomotion at pasture. 
1963, Langlands et al. 1963, Blaxter 1967) or by direct measurement on range (Young and Corbett 1972, Sánchez and Morris 1984). Because of the uncertainties about the reliability of these techniques, energy cost of various activities estimated using calorimetric techniques can be used in conjunction with direct field observations to estimate energy expended in daily activitics of free-ranging animals. The usual procedure is a factorial method, whereby the energy expenditure is estimated from calorimetric determination of the energy cost of various activities. The energy cost of each activity is then multiplied by the total time spent by free-ranging animals in that activity and total daily extra energy expended is calculated by summation. Most of the energy required by the grazing animal is due to standing, eating, and locomotion. The contributions of other activities are usually considered negligible. Data on energy expenditure of goats (Lachica 1993) are scarce. Most recommendations have been obtained by feeding trials (i.e. NRC 1981) or have been derived from other ruminant species which have been proved to be misleading (Prieto et al. 1990, Aguilera et al. 1990). Our objectives were to observe and quantify the grazing activities of goats and to estimate their energy expenditure on open range.

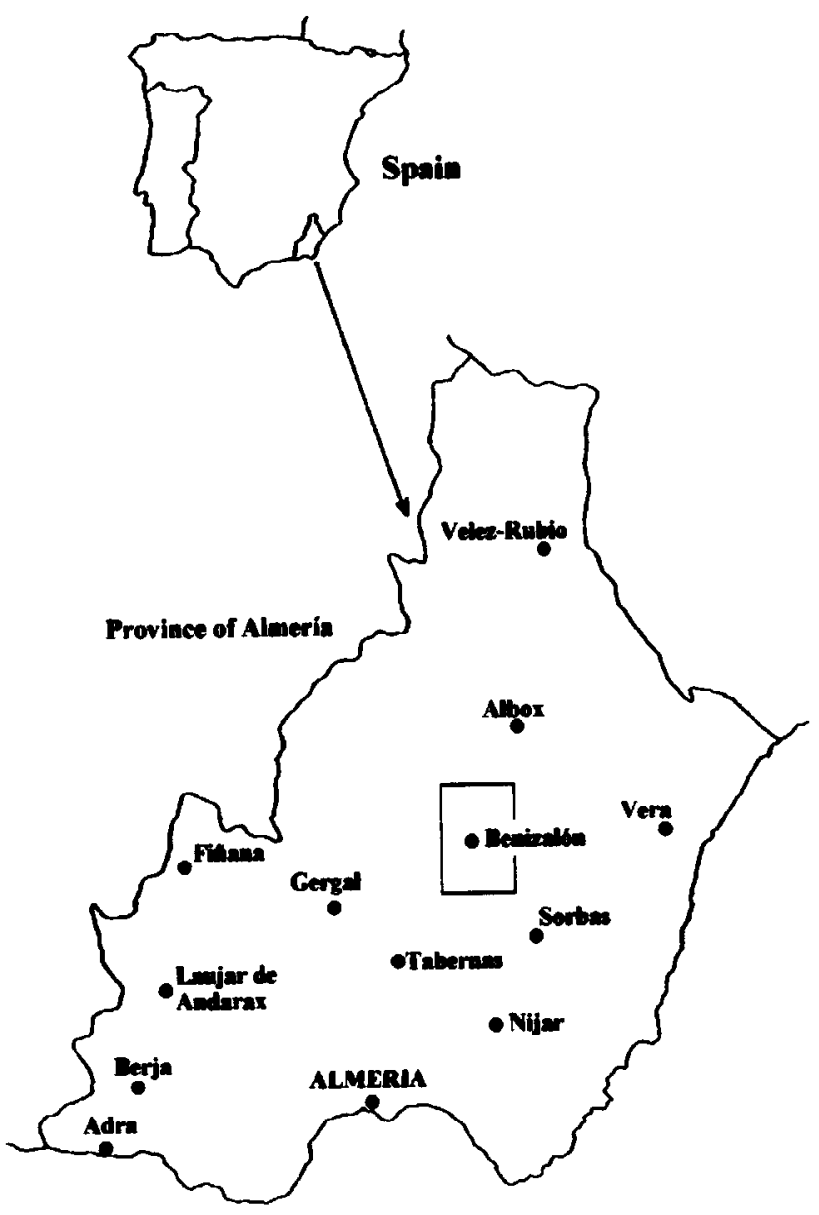

Fig. 1. Study area.

\section{Study Area}

The study was carried out at the 130-ha "Los Pajares" pilot zone, in a small valley located in the Filabres mountain-range, near Benizalon, in the province of Almería, in southern Spain (Fig. 1) (latitude $37^{\circ} 11^{\prime} 40^{\prime \prime} \mathrm{N}$ and longitude $2^{\circ} 15^{\prime} \mathrm{W}$ ). The topography is rugged, with small hollows and slopes of up to $70 \%$. Average elevation is $865 \mathrm{~m}$ above sea level, with local elevation variations of 735 to $1,025 \mathrm{~m}$. The climate is Mediterranean of semi-arid characteristics (De Martonne index: 12.8), consisting of hot, dry summers and mild winters. The mean annual precipitation is $324 \mathrm{~mm}$. Summer is characteristically dry, with the minimum average precipitation being $2.2 \mathrm{~mm}$ in July. Seasonal temperatures range from $8.9^{\circ} \mathrm{C}$ in January to $23.0^{\circ} \mathrm{C}$ in August, with mean maximum temperature values in the hottest month of up to $35-40^{\circ} \mathrm{C}$.

The landscape is characterized by woody plants and perennial grasses resulting from the degradation of the native Mediterranean communities. The vegetation is dominated by Anthyllis cytisoides, Artemisia barrelieri and Stipa tenacisimae. The most abundant plant species of interest for goat production are listed in Table 2. A catalogue of the vegetation of the area has been published by Robles (1990). The study area was chosen because of its geographical location, plant diversity, and representative flock of goats.

\section{Materials and Methods}

The experimental flock was composed of 72 head ( 2 males and 70 lactating females) in Autumn 1990 and of 87 head (3 males, 65 lactating females and 19 growing goats) from Summer 1991. The goats were of the "Granadina", "Malagueña" and "Serrana" breeds and their respective cross-breeds. After morning milking, the goats grazed once (winter) or twice (autumn, spring, and summer) during the day under the supervision of a shepherd and his family and then returned to an enclosed shed, in which they spent

Table 2. Plant species of interest for goat production in "Los Pajares" pilot zone.

\begin{tabular}{cl}
\hline \hline Woody plants & \\
Larger & $\begin{array}{l}\text { Anthyllis cytisoides, Artemisia barrelieri, } \\
\text { Ephedra fragilis, Retama sphaerocarpa, } \\
\text { Rhamnus lycioides }\end{array}$ \\
Smaller & $\begin{array}{l}\text { Fumana laebipes, Fumana thimifolia, } \\
\text { Lavandula multifida, Phagnalon saxatile }\end{array}$
\end{tabular}

Herbaceous

Perennial

Lathyrus clymenum, Plantago albicans, Dactylis glomerata

Annual

Erucastrum virgatum, Sanguisorba minor, Astragalus hamosus, Astragalus sesameus, Biserrula pelecinus, Lupinus angustifolius, Ornithopus compressus, Trifolium glomeratum Trifolium campestre, Vicia sativa, Sonchus oleraceus, Poa bulbosa

Exotic agricultural plants 
the night. Concentrates were provided in autumn and winter. The type of goat management is considered as semi-extensive, for commercial milk production (annual average of 280 liters) and meat (especially carcasses of young kids).

Direct observation (Prieto et al. 1991a, 1991b) was used to measure total distance walked, vertical ascent, or descent, and other grazing activities. The track of a randomly selected lactating female was followed on foot by one observer for 10 minutes for locomotion or for 1 minute by another observer for grazing. This single animal was assumed to be a reliable indicator of flock activity under grazing conditions. At the end of the observation period the nearest goat was followed in a similar way. The procedure was repeated many times during the day throughout 2 consecutive days during each of 4 seasons. In total, 2 observers were used for locomotion measurements (summer values of one observer are missing) and a third observer was used for other grazing activities, such as behaviour and feeding habits (Barroso et al. 1991). The method allows a number of animals to be monitored with minimal labor. Goats had gentle dispositions and were easily approached while grazing. Experiments were conducted from October 1990 to July 1991.

For locomotion studies, each observer carried 1 pedometer and 1 altimeter. The pedometer (Walkman, Walk, and Jog Meter WJ531, Yamax Corporation, Yokohama, Japan) was attached vertically to the observer's belt. The distance travelled is recorded on a digital indicator and subdivided from $25 \mathrm{~m}$ up to $100 \mathrm{~km}$. A stride indicator allows adjustement of the instrument to the step length of the bearer. Several tests of the accuracy of the pedometers were conducted, at the beginning of each trial. The corresponding calibration factors of the instruments were obtained by dividing a known distance walked by the pedometer reading. These values were employed to convert pedometer readings into actual distances walked. The altimeters employed to determine the vertical ascent or descent (Altiplus N1, Pretel, France) are electronic instruments with several functions (altitude, altitude variation, temperature, barometric pressure). Altitude is calculated from atmospheric pressure with a resolution of 1 meter and ranged from -256 to $9,999 \mathrm{~m}$. Temperature ranged from $-25^{\circ} \mathrm{C}$ to $55^{\circ} \mathrm{C}$, with an accuracy of about $1^{\circ} \mathrm{C}$.

The energy expenditure of locomotion was calculated from both the horizontal and vertical (ascent and descent) components of goat's travel (by means of pedometer and altimeter readings) and the corresponding energy cost $\left(3.35\right.$ and $31.1 \mathrm{~J}^{-} \mathrm{kg}^{-1} \mathrm{~m}^{-1}$ for horizontal travel and vertical ascent, respectively) and energy recovery $\left(-13.6 \mathrm{~J}^{-} \mathrm{kg}^{-1} \cdot \mathrm{m}^{-1}\right.$ for vertical descent), which had been obtained by calorimetry with a confinement respiration chamber (Lachica 1993). The results were extrapolated to total time spent by the goats on range during each of 4 seasons and expressed in terms of animals of average live-weight. For example, a $38 \mathrm{~kg}$ goat travelling an horizontal distance of $\mathrm{H} \mathrm{m}$, ascending $\mathrm{A} \mathrm{m}$ and desccnding $\mathrm{D} \mathrm{m}$ in the course of 24 hours would expend $38 \times$ $(\mathrm{H} \times 3.35+\mathrm{A} \times 31.1-\mathrm{D} \times 13.6) \mathrm{J}$. The energy expenditure was then compared with the energy requirements for maintenance of the goat, which was previously determined by open-circuit calorimetry (401 kJ/ $\mathrm{kg}^{0.75}$ per day; Aguilera et al. 1990). From these data the increased energy requirements above maintenance due to activity of grazing goats were calculated.

Treatment effects on locomotion activities within each season were analyzed from data taken by 2 observers throughout 2 consecutive days by means of the one-way analysis of variance, where season was used as error for the analysis, and because the data set was unbalanced in summer, due to the lack of data from 1 observer, Bonferroni's test was used to determine significant diferences $(\mathrm{P}<0.05)$ among means.

The total phytomass and forage phytomass of pilot zone (130 ha) was evaluated in a previous work (Robles et al. 1991). The method of Point-Centred Quarter (Mueller-Dambois and Ellenberg 1974) and the allometric relationship phytomass/phytovolume were used for shrubs and the plot method for herbaceous biotipes. The values of total phytomass and forage phytomass were estimated as 987.9 and $541.4 \mathrm{~kg} / \mathrm{ha}$, the latter value corresponding to 3,435.9 MJ ME/year/ha.

\section{Results and Discussion}

Activities were divided into several major categories: grazing, defined as the time spent searching for and ingesting forage; walking, defined as the movement from one place to another without grazing; resting, defined as no activity (standing or lying); and others (socializing, etc.). Grazing, walking, and standing were the primary activities of the goats throughout the study period (values of activities other than walking in summer are missing), accounting for, on average, 57,27 , and $13 \%$ of the animal-day period, respectively (Table 3). Distinct seasonal trends are apparent in the data. Grazing activity climbed to a peak (70\%) in winter and declined over spring and autumn (52 and $48 \%$, respectively). A similar trend was observed for walking (26, 22 and $21 \%$ throughout winter, spring and autumn). Animal travel increased during the dry season (summer, 37\%).

Table 3. Seasonal changes in daily activities (\%) of the goat on range. (Values are means of $\mathbf{2}$ days of observation)

\begin{tabular}{lccccc}
\hline \hline & Grazing & Walking & Standing & Lying & Others \\
\hline & -10 & & \\
Autumn & 48.4 & 20.9 & 19.0 & 11.5 & 0.2 \\
Winter & 70.0 & 26.4 & 2.2 & 0 & 1.5 \\
Spring & 51.5 & 22.0 & 18.5 & 7.4 & 0.7 \\
Summer & - & 36.8 & - & - & - \\
$\overline{\boldsymbol{x}} \pm \sigma / V_{\mathbf{n}}$ & $56.6 \pm 5.51$ & $26.5 \pm 3.14$ & $13.2 \pm 4.51$ & $6.3 \pm 2.75$ & $0.8 \pm 0.31$ \\
\hline
\end{tabular}

Previous work on feeding habits in the same pilot zone (Barroso et al. 1991) demonstrated that a goat's diet changes depending on seasonal availability. Annually, $54 \%$ of daily feed intake corresponded to woody plants. Grassland use was high throughout the seasons, being greatest in summer (46\%) and lowest in winter $(36 \%)$.

No differences $(\mathrm{P}>0.05)$ were found when comparing locomotion activities from 2 observers, so pooled values of the different activities were calculated. Somlo et al. (1991) concluded that pedometers are inaccurate when carried by goats and were only adequate to measure distances when used by humans. The average pedometer calibration factors (distance travelled/distance recorded) and their coefficients of variation indicate the reliability of the 
Table 4. Mean daily locomotion activities of the goat at pasture in the study area. (Values are means of 2 observers throughout 2 consecutive days)*

\begin{tabular}{lcccc}
\hline \hline & $\begin{array}{c}\text { Time spent at } \\
\text { pasture }\end{array}$ & $\begin{array}{c}\text { Distance } \\
\text { travelled }\end{array}$ & $\begin{array}{c}\text { Vertical ascent } \\
\text { or descent }\end{array}$ & Mean speed \\
\hline Autumn & $(\mathrm{h})$ & $(\mathrm{m})$ & $(\mathrm{m})$ & $(\mathrm{m} / \mathrm{min})$ \\
Winter & $5.7^{\mathrm{a}}$ & $3482^{\mathrm{a}}$ & $139^{\mathrm{a}}$ & $10.2^{\mathrm{a}}$ \\
Spring & $6.0^{\mathrm{ab}}$ & $4137^{\mathrm{ab}}$ & $181^{\mathrm{a}}$ & $11.5^{\mathrm{a}}$ \\
Summer & $7.7^{\mathrm{b}}$ & $3799^{\mathrm{a}}$ & $197^{\mathrm{a}}$ & $8.2^{\mathrm{a}}$ \\
& $7.2^{\mathrm{ab}}$ & $5763^{\mathrm{b}}$ & $153^{\mathrm{a}}$ & $13.3^{\mathrm{a}}$ \\
Annual mean & 6.7 & 4295 & 168 & 10.8 \\
Pooled std. error & 0.22 & 153.5 & 11.2 & 0.50 \\
Range & $(5.1-8.7)$ & $(2982-6725)$ & $(104-253)$ & $(5.7-15.6)$ \\
\hline
\end{tabular}

*Within the same column values bearing different superscripts are significantly different $(\mathrm{P}<0.05)$.

records of distances walked in the present work $\left(\bar{x}_{1}=1.005 \pm\right.$ $0.0213, \mathrm{CV}=7.33 \%, \mathrm{n}=12 ; \bar{x}_{2}=0.984 \pm 0.0459, \mathrm{CV}=16.18 \%$, $\mathrm{n}=12$; for pedometers 1 and 2, respectively). Distance travelled daily by goats on range (Table 4) fluctuated from $5,763 \mathrm{~m}$ in summer to $3,482 \mathrm{~m}$ in autumn, with an annual average of 4,295 $\mathrm{m}$, which represents a mean annual daily speed of $10.8 \mathrm{~m} / \mathrm{min}$. These data were calculated over the whole day, not over the time spent walking. Travel activity peaked in summer and then declined in the other seasons, with a minimum in autumn. The mean annual vertical ascent or descent was $168 \mathrm{~m}$.

Estimated heat production due to locomotion (Table 5) ranged from 56.9 to $34.8 \mathrm{~kJ} / \mathrm{kg}^{0.75}$ per day in summer and autumn, respectively, with an annual mean value of $43.5 \mathrm{~kJ} / \mathrm{kg}^{0.75}$ per day. Assuming a metabolisable energy requirement for maintenance of $401 \mathrm{~kJ} / \mathrm{kg}^{0.75}$ per day (Aguilera et al. 1990) and the corresponding average live weight, these values account for an estimated increased heat production above maintenance on range of 14.2 and $8.7 \%$ in summer and autumn, respectively $(\bar{x}=10.8 \%)$. This agrees with the mean increase of $11 \%$ estimated for free ranging sheep by Blaxter (1967) but is markedly lower than values reported for free ranging cattle and sheep grazing (Table 1). For goats, the National Research Council (NRC 1981) considers a mean value of $424 \mathrm{~kJ} \mathrm{ME} / \mathrm{kg}^{0.75}$, which is slightly greater than our experimental value, to determine their maintenance requeriments and then makes an extra allowance of energy to be added to the maintenance requeriments. For increased muscular activity of

Table 5. The energy cost of locomotion of the goat at pasture in the study area during the different seasons. (Values are means of 2 observers throughout 2 consecutive days )

\begin{tabular}{lccc}
\hline \hline & Live weight & Heat production (HP) & $\begin{array}{c}\text { Estimated increased } \\
\text { HP over } \\
\text { maintenance }\end{array}$ \\
\hline Autumn & $(\mathrm{kg})$ & $\left(\mathrm{kJ}^{2} / \mathrm{kg}^{0.75}\right)$ & $(\%)$ \\
Winter & 37 & $34.8^{\mathrm{a}}$ & $8.7^{\mathrm{a}}$ \\
Spring & 35 & $41.4^{\mathrm{ab}}$ & $10.3^{\mathrm{ab}}$ \\
Summer & 40 & $40.7^{\mathrm{ab}}$ & $10.1^{\mathrm{ab}}$ \\
Annual mean & 45 & $56.9^{\mathrm{b}}$ & $14.2^{\mathrm{b}}$ \\
Pooled std. error & 0.0 & 43.5 & 10.8 \\
TWithin the same column values bearing different superscripts are significantly different \\
(P<0.05). \\
MEm=401 kJ/kg
\end{tabular}

animals under grazing conditions: a $25 \%$ increment in the case of light activity, a 50\% increment on semiarid rangeland pasture and on slightly hilly land, and a $75 \%$ increment in case of long-distance travel on sparsely vegetated grassland or on mountainous transhumance pasture was used. The application of these tabulated values to our data would overestimate the results when compared with the experimental values found. This indicates that it is inapropriate to extrapolate theorical allowances for activity to all conditions. A direct estimation of the additional expenditure of energy under grazing conditions, as done in this work, would be more advisable.

\section{Conclusions}

The method used appear to be adequate to simulate and quantify grazing activities of goats on open range by means of direct observation. It is simple and easy to apply to field conditions, requiring only 1 observer for locomotion studies. The results also showed that the energy cost of locomotion represented a substantial contribution to the energy expenditure of goats on range. This study will facilitate a more accurate estimation of the stocking rate in the study area.

\section{Literature Cited}

Aguilera, J.F., C. Prieto, and J. Fonollá. 1990. Protein and energy metabolism of lactating Granadina goats. Br. J. Nutr. 63: 165-175.

Barroso, F.G., C.L. Alados, and J. Boza. 1991. Estudio sobre hábito alimentario del ganado caprino en la Sierra de Filabres, área representativa de las zonas áridas del sureste ibérico. XXXI Reunión Científica de la Sociedad Española para el Estudio de los Pastos (S.E.E.P.), Murcia, Spain.

Blaxter, K.L. 1967. The Energy Metabolism of Ruminants. Hutchinson, London. pp. 110-112.

Brockway, J.M. 1978. Escape from the chamber: alternative methods for large animal calorimetry. Proc. Nutr. Soc. 37:13-19.

Coop, I.E. and M.K. Hill. 1962. The energy requirements of sheep for maintenance and gain. 2. Grazing sheep. J. Agr. Sci. 58:187-199.

Corbett, J.L., P.J. Lamglands., and Boyne, A.W. 1961. Energy expenditure for maintenance in cows strip grazing. In: Proc. VIII Int. Tarzucht Congr. Hauptberichte. Hamburg. pp. 193-194.

Hutton, J.B. 1962. Maintenance requirements of dairy cattle. Proc. N. Z. Soc. Anim. Prod. 22:12-34.

Lachica, M. 1993. Estimación del gasto energético de la actividad física en ganado caprino. Comparación de técnicas calorimétricas y no calorimétricas (Estimation of the energy expenditure due to physical activity in goats. Comparison between calorimetric and non-calorimetric techniques). PhD Thesis. University of Granada, Spain.

Lambourne, L.J. and T.F. Reardon. 1963. Effect of environment on the maintenance requirements of Merino wethers. Aust. J. Agr. Res. $14: 272-292$.

Langlands, J.P., J.L. Corbett, L. McDonald, and G.W Reid. 1963. 2. Grazing sheep. Anim. Prod. 5:1-9; 11-16.

Mueller-Dambois, D. and H. Ellenberg. 1974. Aims And Methods of Vegetation Ecology. John Willey and sons. N.Y.

National Research Council. 1981. Nutrient Requeriments of Domestic Animals, Publication no.15 Washinton, D.C: Nat. Acad. Press.

Osuji, P.O. 1974. The physiology of eating and the energy expenditure of the ruminant at pasture. J. Range Manage. 27: 437-443.

Prieto, C, J.F. Aguilera, L. Lara, and J. Fonollá, J. 1990. Protein and energy requirements for maintenance of indigenous Granadina goats. Br. J. Nutr. 63:155-163. 
Prieto, C., R. Somlo, F. Barroso, and J. Boza. 1991a. Estimación del gasto energético del caprino en pastoreo en la comarca de Andarax (Almería). I. El costo de la locomoción (The energy expenditure of the goat on range in the region of Andarax (Almería). I. Energy cost of locomotion). Arch. Zootec. 146:55-72.

Prieto, C., R. Somlo, F. Barroso, and J. Boza. 1991b. Estimación del gasto energético del caprino en pastoreo en la comarca de Andarax (Almería). II. El costo de la ingestión de alimento (The energy expenditure of the goat on range in the region of Andarax (Almería). II. Energy cost of eating). Arch. Zootec. 146:73-83.

Prieto, C., M. Lachica, F. Barroso, and J.F. Aguilera. 1992. Energy expenditure by grazing animals. 43rd. Annual Meeting of the EAAP. Madird. Personal communication.

Reid, J.T. 1958. Pasture evaluation-Nutritional and economic aspects of feed utilization by dairy cows. C.R. Hoglund (ed.). Iowa State Coll. Press.

Robles, A.B. 1990. Evaluación de la oferta forrajera y capacidad sustentadora de un agrosistema semiárido del sureste iberico. $\mathrm{PhD}$ thesis. University of Granada, Spain.
Robles, A.B., J.L. González, T.C. Morales, J. and Boza. 1991. Evaluación de la fitomasa en comunidades arbustivas de interés ganadero del suerte árido español: Experiencia piloto "Los Pajares (Benizalón, Almería). Serie: Congresos. Pastoralismo en zonas áridas mediterráneas. S.E.E.P. Murcia, 20-24 Mayo, 1991.

Sánchez, M.D. and J.G. Morris. 1984. Energy expenditure of beef cattle grazing annual grassland. Can. J. Anim. Sci., Suppl. 64:332-334.

Somlo, R., C. Prieto, F. Barroso, M. Bustos, and J. Boza. 1991. Simulación de la distancia recorrida por el caprino en pastoreo mediante podómetros (Simulation of the distance travelled by the goat at pasture by means of pedometers). Arch. Zootec. 40 (147):131-138.

Wallace, L.R. 1955. Intake of dairy cows at pasture in relation to their productive performance. Anim. Res. Div. New Zealand Dept. Agr. Rep. 1955-6.

Whitelaw, F.G. 1974. Measurement of energy expenditure in the grazing ruminant. Proc. Nutr. Soc. 33:163-172.

Young, B.A. and J.L. Corbett. 1972. Maintenance energy requirement of grazing sheep in relation to herbage availability. I. Calorimetric estimates. Aust. J. Agr. Res. 23:57-76.

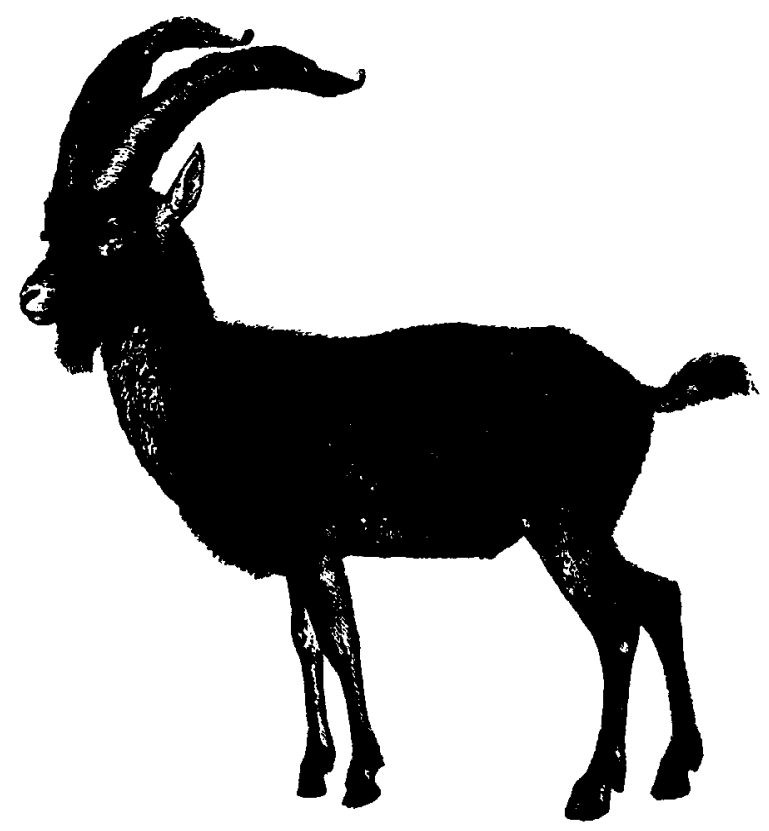

